\title{
THE INFLUENCE OF FRONTLOADING STRATEGY TOWARD STUDENTS' LISTENING COMPREHENSION
}

\author{
Mukminatus Zuhriyah \\ English Language Education Department, University of Hasyim Asy'ari, Indonesia \\ zoehrea@gmail.com
}

\begin{abstract}
All English departments provide the listening courses that must be studied by their students. In fact, the students often find difficulties in understanding the listening texts so that their listening comprehension becomes low. This condition also happens to the students of English department of UNHASY. One of the causes of it is the teaching strategy for listening which is not appropriate. Therefore, the researcher implemented frontloading strategy for teaching listening in this study. The purpose of this study was to know whether or not frontloading strategy influenced the students' listening comprehension. The research method used was quasi experiment with the design of pretest posttest nonequivalent control group. The population and the sample of the research were the two classes of the second semester students of English education department of UNHASY in the academic year of 2018/2019. After the implementation of frontloading strategy in experimental class and direst listening in control class, the students' post listening comprehensions were compared by using independent sample t-test whose result was that sig. (2-tailed) (0.004) was lower than 0.05. In short, it is concluded that frontloading strategy influences students' listening comprehension.
\end{abstract}

Keywords: Influence, Frontloading Strategy, Listening Comprehension

\section{INTRODUCTION}

The people as the social humans cannot avoid having interaction among others in their community. They communicate one another by using both active and passive communication in order to fulfill their need. The active communication is mostly used in daily interaction. Dealing with this condition, listening ability is the first thing to be acquired for communicating. The ability of listening must come at first before the communication ability. To be involved in the conversations or dialogues by having good responses, the people must be good at listening. In order not to get some misunderstanding in the discussion, the people must listen carefully to the things which are being discussed and then, understand them. After understanding, they can join the discussion well. In short, listening becomes the first ability that the people must have before three other language skills.

It also occurs when learning a foreign language especially English, listening must be done first. Learning a foreign language is similar to the learning a language that is experienced by the baby. At the first time, the baby will do listening to what the people that 
Anglo-Saxon : Jurnal Ilmiah Program Studi Pendidikan Bahasa Inggris Vol. 11, No 1: 68-80 Juni 2020

P-ISSN 2301-5292 E-ISSN 2598-9995

are surrounding him or her are saying. After he or she can listen, he or she will imitate to say the words or the sayings that are heard. The baby will listen to the voices and sounds that are existing in his or her environment before he or she learns to speak, read and write (Cahyono \& Widiati, 2009). There is also a fact that the baby who cannot listen usually cannot speak. It is a proof that listening must be acquired before others.

Eventhough many of us argue that it is better to learn speaking at the first time when studying English, actually what the people do first at the time they are learning speaking is listening. They can immitate the pronunciation of some words well by listening to their teachers' pronunciation or the native speakers' pronunciation. They are also able to practice some conversations after listening to the examples of the conversations which are given by the teacher. These listening activities are unconciously done because they focus on their goal of studying speaking.

Listening is a very important part to be learnt in English learning. It is because listening leads the learners of English to the mastery of the speaking, reading and writing abilities. Listening gives the foundation for all language aspects (Nor, 2014). In addition, former researchers had found the facts as follows:

1. More than 45 percent of the people's communication is used for listening

2. The way how the people to know something is 80 percent done through listening

3. And listening also becomes the people's way to learn almost 83 percent of what they are learning (Canpolat, Kuzu, Yıldırım, \& Canpolat, 2015).

Therefore, listening cannot be ignored in the teaching and learning of English. Listening is a kind of ability for receiving and interpreting the speakers' messages in the process of communication (Yusnida, Muslem, \& Manan, 2017). Seeing the importance of the listening role, the students must be taught listening indeed. From listening, the students will learn to discriminate between the sounds, understand the speakers' accent or pronunciation, vocabulary and grammatical structures and comprehend the sayings of the speakers. Those are the reasons why all English departments in universities always provide listening courses for three up to four semesters in which each semester has two credit hours. Every student of English department must get and pass these listening courses. 
Anglo-Saxon : Jurnal Ilmiah Program Studi Pendidikan Bahasa Inggris Vol. 11, No 1: 68-80 Juni 2020

P-ISSN 2301-5292 E-ISSN 2598-9995

Listening is a process which is complex by involving various sources such as phonetic, phonological, semantic, lexical, prosodic and others (Batova, 2014). So that it is a common thing if many of the students still find difficulties in learning listening. They feel difficult to catch what the speakers are saying. They often do not understand the words that the speakers are telling about. They also sometimes do not know the spelling of the words which are said by the speakers. They only can imitate the pronunciations of the speakers' words without knowing the true spelling of those words. All of these conditions make the students fail to comprehend the listening text well. Their listening comprehension becomes low. Besides that, the strategy of teaching and learning of listening also has a significant impact to this low listening comprehension. It is what happens to the listening comprehension of English department students of UNHASY. That is why it is very demanded to teach listening to the students by using the appropriate teaching strategy.

Frontloading strategy was selected to be applied in the listening class of this study. This strategy activates the students' prior knowledge about the materials which will be studied so that the students can connect the knowledge that they have already had with what they are listening to. The activities that can be done for doing this kind of strategy are by giving the students a list of vocabulary about the material to be studied and speaking the listening theme before the listening text is played (Vega, 2016). These two activities differentiate frontloading strategy from other listening strategies which are usually used for teaching listening.

Some previous studies which have conducted frontloading strategy in English language classroom have proven that frontloading strategy is a very effective strategy for teaching English. Frontloading strategy could improve the vocabulary mastery (Purwasih, 2014) and the reading comprehension (Citra \& Fitrawati, 2018; Maulida, 2016). Purwasih (2014) applied frontloading strategy in the experimental class when teaching vocabulary. After the treatment was done, she compared the scores of vocabulary mastery of experimental class and control class. The mean score of experimental class was higher and the mean difference was also significant. These findings brought her to the conclusion that frontloading strategy was effective for increasing students' mastery of vocabulary. Next, Maulida (2016) 
Anglo-Saxon : Jurnal Ilmiah Program Studi Pendidikan Bahasa Inggris Vol. 11, No 1: 68-80 Juni 2020

P-ISSN 2301-5292 E-ISSN 2598-9995

also implemented frontloading in her English teaching but it was in class of reading. She did five times treatment for her reading class. Afterward, she compared the scores of pretest and posttest on her students' reading comprehension. The result was that the scores of posttest got improvement. She concluded that frontloading strategy was effective to improve the ability of the students in comprehending the English text. She also used the questionnaires to know the students, responses about the implementation of frontloading strategy. She got the data that frontloading strategy could make the students feel fun and become enthusiastic in reading class. Furthermore, Citra \& Fitrawati (2018) found some advantages of applying frontloading strategy in class of reading, such as helping students to comprehend the texts, preparing the students before reading and improving the students' vocabulary.

All of the results of the former researches above explained the success of frontloading strategy in improving the students' English skill and mastery, specifically on reading comprehension and vocabulary mastery. However, there is no research which has implemented frontloading strategy on listening class. It is why the researcher focuses on the implementation of strategy of frontloading for class of listening on this research. Meanwhile, the research problem of this study is whether or not frontloading strategy has significant influence toward the students' listening comprehension. Afterward, the hypothesis of this research is that frontloading strategy influences the students' comprehension on listening significantly.

\section{METHODOLOGY}

This study used quasi experimental research by applying the design of non equivalent pretest posttest control group. There were one control group and one experimental group in this study. Then, the population of the research was the second semester students of English education department of Hasyim Asy'ari University (UNHASY) in the academic year of 2018/2019. They were divided into two classes which consisted of eighteen students of each. The researcher used total sampling so that those two classes became the sample. This kind of sampling was done because there were only two classes for semester two in that academic year. To get the class which would be the control class and the experimental class, the lottrey 
Anglo-Saxon : Jurnal Ilmiah Program Studi Pendidikan Bahasa Inggris Vol. 11, No 1: 68-80

Juni 2020

P-ISSN 2301-5292

E-ISSN 2598-9995

was used. The result was that class A became the experimental class and class B as the control class. Class A as an experimental class was taught listening by using frontloading strategy. Direct listening was applied in class B or the control class. This research was carried out in the class of interpretive listening.

The researcher used pretest and posttest of listening as the instruments. On these two tests, the students were asked to interpret the listening texts that they had just heard by using their own vocabularies based on their understanding. All the students of class A and class B were given pretest of listening comprehension before the implementation of frontloading strategy and direct listening. It was done to know their prior listening comprehension. After that, frontloading strategy and direct listening were implemented. Both of the strategies were applied in three meetings. Next, the students got the posttest of listening comprehension to know their post listening comprehension. These were the ways in collecting the data for this study.

To analyze the data, the researcher used independent samples test to answer whether or not frontloading strategy influences the students' listening comprehension. The data which were used for this test were the scores of listening posttest from experimental class and control class. The scores of those two classes were compared by using independent samples test. Before that, the scores of the two classes had to be analyzed their normality and homogeneity. After the data was in the normal distribution and homogenous, independent samples test was carried out. All of the computations were done by using SPSS version 17.0. Additionally, to find that the improvement of the students' listening comprehension before and after being taught by using frontloading strategy was significant or not, the scores of pretest and posttest of listening comprehension of the students in the experimental class were also analyzed by using paired samples test.

\section{FINDING AND DISCUSSION}

Frontloading strategy was applied in the experimental class for three meetings. The procedures that were done in implementing frontloading strategy for listening class are described as follows: 
Anglo-Saxon : Jurnal Ilmiah Program Studi Pendidikan Bahasa Inggris Vol. 11, No 1: 68-80

Juni 2020

P-ISSN 2301-5292

E-ISSN 2598-9995

a. The lecturer displayed a list of vocabularies in the PPT, exactly ten vocabularies which had relation to the materials of listening

b. The students were given time for five minutes to find the meaning of those vocabularies that have been displayed in the dictionary if they did not know the meanings yet

c. All the students answered the lecturer's questions about the meanings of the vocabularies presented in PPT

d. The lecturer asked all the students to guess what topic was going to talk if the vocabularies which are used are as what exists in PPT

e. After the students got the right answer of the topic being discussed, the students were asked to have speaking with their partner for five minutes about that topic

f. The listening text was played after a five-minute speaking had been done.

g. After the recording text was played three times, the students were demanded to answer all the questions in the exercises having been given

h. The students were pointed to answer the questions by the lecturer and they got the right answer from the lecturer if they got mistake when answering the questions.

The different peocedures were implemented in the control class. Control class got direct listening whose procedures are as follows:

a. The lecturer asked the students to pay attention to the listening texts that would be played

b. The students were allowed to take notes of the listening texts that they were listening to

c. The lecturer repeated to play the listening texts five times

d. The students were requested to answer the listening exercises that had been prepared.

e. The lecturer pointed the students to answer the exercises until all the questions were answered

f. The lecturer gave the correct answer when the students got mistakes in answering the questions. 
Anglo-Saxon : Jurnal Ilmiah Program Studi Pendidikan Bahasa Inggris Vol. 11, No 1: 68-80

Juni 2020

P-ISSN 2301-5292

E-ISSN 2598-9995

All of those activities were always done in those three meetings for experimental class and control class. The students of experiment and control classes did the posttest of listening comprehension after those three meetings.

The scores of listening comprehension from posttest of experimental class and control class were, then, compared by using independent samples test. Before this t-test was used, the normality and the homogeneity of all the scores must be known at first. The independent samples test could be applied because they were in the normal distribution and homogeneous. The result of independent samples test is presented in the following table.

\begin{tabular}{|c|c|c|c|c|c|c|}
\hline & & \multicolumn{5}{|c|}{ t-test for Equality of Means } \\
\hline & & $\mathbf{t}$ & df & $\begin{array}{l}\text { Sig. (2- } \\
\text { tailed) }\end{array}$ & $\begin{array}{c}\text { Mean } \\
\text { Difference }\end{array}$ & $\begin{array}{l}\text { Std. Error } \\
\text { Difference }\end{array}$ \\
\hline \multirow[t]{2}{*}{$\begin{array}{l}\text { Listening } \\
\text { Comprehension }\end{array}$} & $\begin{array}{l}\text { Equal } \\
\text { variances } \\
\text { assumed }\end{array}$ & 3.120 & 34 & .004 & 6.6667 & 2.1368 \\
\hline & $\begin{array}{l}\text { Equal } \\
\text { variances } \\
\text { not } \\
\text { assumed }\end{array}$ & 3.120 & 33.879 & .004 & 6.6667 & 2.1368 \\
\hline
\end{tabular}

The above table shows that sig. (2-tailed) of independent samples test which is 0.004 is lower than 0.05. This tells that the mean scores of students' listening comprehension of experimental class and control class significantly differ. The average score of listening comprehension of students in experimental class after being taught by using frontloading strategy is 78.6. Meanwhile, the average students' listening comprehension after they were taught by using direct listening strategy is 71.9 . It can be stated that the students' listening comprehension of experimental class is better than the listening comprehension of the students in control class. Thus, it leads to the conclusion that frontloading strategy influences the students' listening comprehension.

This independent samples test is strengthened by the result of paired samples test of the students' listening comprehension in experimental class before and after the strategy of frontloading was implemented. The table below shows the result of paired samples test.

Table 2. Result of Paired Samples Test on Experimental Class 


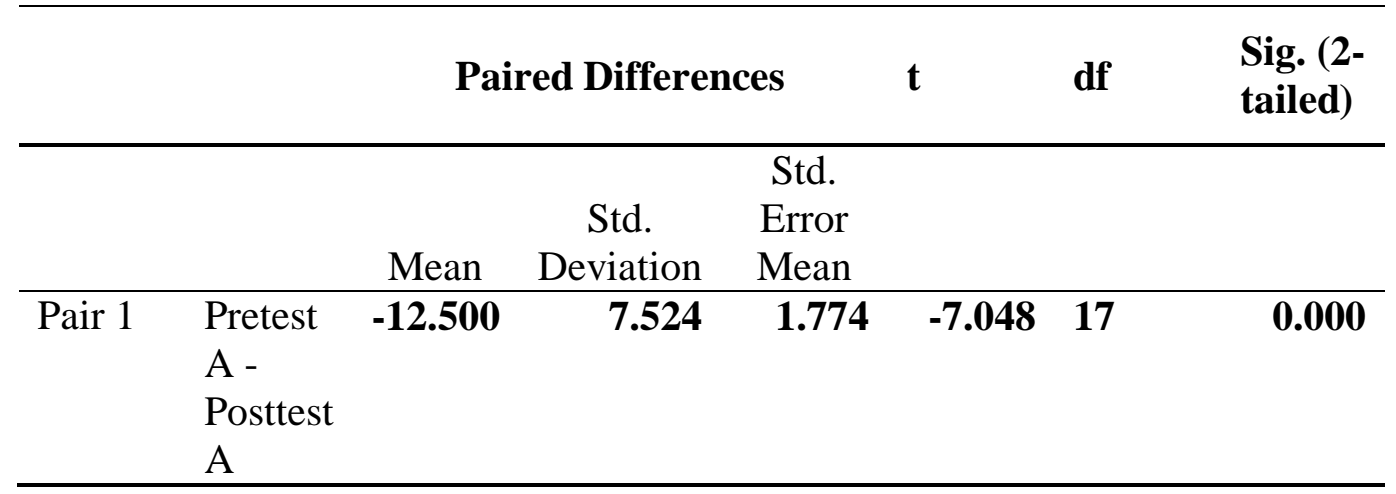

Based on the data above, it can be known that sig. (2-tailed) of paired sample test is 0.000. It is lower than 0.05. It shows that the difference of mean of the comprehension of the students in listening is significant. Before the students were taught listening by using frontloading strategy, their listening comprehension mean was 66.1. Their mean became 78.6 after the frontloading strategy was implemented in their listening class. In short, it can be said that frontloading strategy is effective for teaching listening.

The two tables above talk that the strategy of frontloading has significant influence toward the students' listening comprehension. Frontloading strategy is very helpful in comprehending the listening text which is being studied. It is because the students get the vocabularies which are related to the material in the listening text before they listen the whole listening text. The students are also invited to speak about something related to the materials for a while. Those two kinds of activities make the students easier to catch what the speakers are saying in the listening text. They are already directed to the theme of the material which they are going to learn before listening to it. Their prior knowledge of the materials is activated so that they are easy to get through when listening to the recording text.

Having known some vocabularies that are used in the recording text helps the students to recognize the words in the listening quickly. They can directly follow the story or the conversation which are being told in listening. They are also able to imagine what the speakers are saying. They can predict the exact words that are sounded. Even though there are many words of English that have the same sounds, they do not get any mistake anymore about the words that they have heard in the listening. Their lecturer has already provided those words in the previous session before coming to the real listening text. Besides, they can 
Anglo-Saxon : Jurnal Ilmiah Program Studi Pendidikan Bahasa Inggris Vol. 11, No 1: 68-80

Juni 2020

P-ISSN 2301-5292

E-ISSN 2598-9995

distinguish the words that have the same pronunciations because of the context. It means that the students have already been able to pass the obstacles in listening that contain the confusing sounds as the linguistic competence. The students' linguistic competence which is still lack often causes the poor comprehension in listening (Vega, 2016).

The data also shows that the students' listening comprehension became better after the students were provided a list of vocabularies before listening. It is a proof that vocabulary has an important role for students' ability in understanding the listening text. It is already researched before that vocabulary knowledge (breadth and depth) has positive and significant correlation with academic listening comprehension (Teng, 2016). Amount of the vocabulary that the students have when listening is very helpful. The students will connect to what they are listening to by having supplies of the vocabularies easily. They will guess the meaning of the words that they hear more efficiently and accurately by having a lot of vocabularies. Yet, it will be difficult to recognize the words which are being spoken in the listening text for the students who have few vocabularies.

Additionally, having conversation or speaking for a while about the words related to the materials of the listening makes the students activate their prior knowledge. Prior knowledge in this case is about what has already existed in their mind. When speaking with their partners about the vocabularies which are given by their lecturer, the students recall their previous learnings or their previous experiences that they have ever had. The students who have already known the similar stories as the listening theme, they will try to remember many things which have relation to the materials which are being learnt. They exchange their previous knowledge with their friends in this activity. They also will get the clarification about their knowledge whether their knowledge is true or not. This speaking activity helps the students much in not only reactivating but also clarifying as well as avoiding misconception of their prior knowledge. This prior knowledge of the topic of listening text will make the students grasp the meaning of the words which are spoken by the speakers in the recording texts quickly. But, the students who do not have any knowledge will have the new information from their conversation although the time for the conversation is only a few minutes. This condition will take place when the partner of their speaking know nothing 
about what they are discussing and the other student has own experience before. Something happens next is that the partner who has known about the topic will share their knowledge to his or her friend. The new information that they get from their speaking partners will become the supply for them in listening to the text. They will be able to link their new information to the content of the listening text. They will be more confident in predicting the meaning of the words which are told by the speakers after getting this new information. This also contributes to the increase of their listening comprehension.

Frontloading strategy brings the changes to the listening learners. It completes the learners with the listed vocabularies and prior knowledge as well as new knowledge that has close relation to the listening materials. The vocabularies which are given and those kinds of knowledge lead them to the better understanding of the recording text which is being played by their lecturer. They can understand the content of the listening text more easily. These facts cause the better listening comprehension that the students of experimental class on this study. The students as the listeners have used their knowledge and apply what they know to what they hear for understanding what the speakers say (Gilakjani \& Ahmadi, 2011).

The different facts are owned by the students in the control class. Generally their listening comprehension is lower. They are invited to do the listening exercises by using direct listening. The lecturer does not do pre-listening activity. What the students do to understand the listening text is pure from the ability that they have already had. The students still get the confusion about the words that they hear. They do not have ability to guess the exact words that come out of the recording texts. It is because direct listening does not serve a help for the students before arriving in the listening session. What they get is only the correction from their lecturer about their listening understanding when the lecturer knows that their answer is not correct.

Direct listening does not provide the vocabularies which are going to be used in the listening texts. In other words, it demands the students to have large vocabularies when coming to the listening class. On one hand, the students who have large vocabularies will survive in this class and on the other one, this situation often makes the students who do not have enough vocabulary give up listening to the recording texts. It is supported by the 
Anglo-Saxon : Jurnal Ilmiah Program Studi Pendidikan Bahasa Inggris Vol. 11, No 1: 68-80

Juni 2020

P-ISSN 2301-5292

E-ISSN 2598-9995

research result which tells that although the students seem to listen to the recording text, in fact, they have given up listening because of their difficulties (Molla \& Tesisa, 2017). The students who are not able to comprehend what the speakers are telling about are often caught to yawn and seem sleepy. If it is permitted, they may be going out from the class because they feel that they do not know anything about the content of the listening texts which are being played by the lecturer. The lack of vocabularies that they experience makes them get difficulties in learning listening through direct listening.

Direct listening also has no serve for both reactivating prior knowledge and giving new information related to the listening topic that will be learnt in the class. It makes the students who have the prior knowledge about the listening materials do not know whether they have true knowledge or not. They do not get the clarification of the knowledge that they have. If they undergo misconception, their misunderstanding will be brought into their interpretation and comprehension of the listening texts. The result of it is that their comprehension on listening becomes wrong so that their listening comprehension is also bad. The same thing also happens to the students who do not have prior knowledge. Their listening comprehension also will not be good if they do not have an innate ability on listening.

Based on the above descriptions about direct listening, it can be known that this strategy has some weaknesses. They are as follows:

a. It does not provide the vocabularies that are involved in the listening materials

b. It does not stimulate the students' prior knowledge which is related to the listening materials

c. It also gives no new knowledge before listening to the recording text.

Those become the causes of the low listening comprehension of the students which are taught listening by using direct listening. The things that can make the students who learn listening by using direct listening have good listening comprehension are the large vocabularies and innate abilities on listening that they have.

\section{CONCLUSION}


Anglo-Saxon : Jurnal Ilmiah Program Studi Pendidikan Bahasa Inggris Vol. 11, No 1: 68-80

Juni 2020

P-ISSN 2301-5292

E-ISSN 2598-9995

The result of this research leads to the conclusion that frontloading strategy influences the students' listening comprehension. It can be seen from the independent sample t-test result of posttest scores on listening comprehension of experimental class and control class that is lower than 0.05. The students' activities which are done in frontloading strategy have more contributions for the significant improvement of the students' listening comprehension in the class of experiment. Their listening comprehension was higher than that of the control class. The students get benefit for comprehending the recording texts which are being learned by having been provided a list of vocabularies that are related to the theme of listening and having done speaking for a while about the material of listening. Really, those two activities which are done before the listening are very beneficial for the students.

To know that frontloading strategy influences the students' listening comprehension, the lecturers and the teachers of English must prepare a list of vocabularies which exist in the listening text. It is better if the vocabularies which are given to the students are the unfamiliar words. After having had the unfamiliar vocabularies and having known their meanings, the lecturers and the teachers must invite the students to speak about the words for a while. Next, the future researchers are suggested to do further research about the same topic as this research because there are still many other areas which are not explored in this research such as the categories of the vocabularies that are given to the students before listening. The researcher of this study only gave the students the vocabularies that seem unfamiliar and have relation to the listening materials.

\section{REFERENCES}

Batova, N. (2014). Academic listening: is there a place for bottom-up processing? International Journal of Education and Research, 1(4), 1-10.

Cahyono, B. Y., \& Widiati, U. (2009). The Teaching of EFL Listening in the Indonesian Context: the State of the Art. TEFLIN Journal, 20(2), 194-211.

Canpolat, M., Kuzu, S., Y1ldırım, B., \& Canpolat, S. (2015). Active Listening Strategies of Academically Successful University Students. Eurasian Journal of Educational Research, (60), 163-180. https://doi.org/10.14689/ejer.2015.60.10 
Anglo-Saxon : Jurnal Ilmiah Program Studi Pendidikan Bahasa Inggris Vol. 11, No 1: 68-80 Juni 2020

P-ISSN 2301-5292 E-ISSN 2598-9995

Citra, Y., \& Fitrawati. (2018). Using Front Loading Vocabulary in Improving Students' Reading Comprehension at Senior High School. Journal of English Language Teaching, 7(4). Retrieved from http://ejournal.unp.ac.id/index.php/jelt

Gilakjani, A. P., \& Ahmadi, M. R. (2011). A Study of Factors Affecting EFL Learners' English Listening Comprehension and the Strategies for Improvement. Journal of Language Teaching and Research, 2(5), 977-988,. https://doi.org/doi:10.4304/j1tr.2.5.977-988

Maulida, R. D. (2016). Frontloading Strategy to Improve EFL Junior High School Students' Descriptive Text Reading Skill. International Seminar on English Language Teaching (ISELT 2016), 189-196.

Molla, B., \& Tesisa, G. (2017). Relationship Between Foreign Language Listening Anxiety and Listening Comprehension. International Journal of Foreign Language Teaching \& Research, 5(19), 12-23.

Nor, H. (2014). The Techniques in Teaching Listening Skill. Journal on English as a Foreign Language, 4(1), 41-51.

Purwasih, I. (2014). The effectiveness of using frontloading strategy in increasing the vocabulary mastery of the seventh grade students of SMP N25 Purworejo in academic year 2013/2014. Muhammadiyah University of Purworejo.

Teng, F. (2016). An In-depth Investigation into the Relationship between Vocabulary Knowledge and Academic Listening Comprehension. TESL-EJ , The Electronic Journal for English as a Second Language, 20(2), 1-17.

Vega, O. (2016). Factors to Consider When Teaching Listening Comprehension in the EFL/ESL Classroom. Mextesol Journal, 40(4), 1-6.

Yusnida, D., Muslem, A., \& Manan, A. (2017). A study of teaching listening. English Education Journal (EEJ), 8(4), 439-456. 